\title{
Growth, parasitic infection and hematology in Colossoma macropomum Cuvier, 1818 fed diets containing Allium sativum
}

\author{
By L. A. K. A. Inoue ${ }^{1}$, P. Oliveira Maciel $^{2}$, E. Gusmão Affonso ${ }^{3}$, C. de Lima Boijink ${ }^{4}$ and M. Tavares-Dias ${ }^{5}$ \\ ${ }^{1}$ Embrapa Agropecuária Oeste, Dourados, Brazil; ${ }^{2}$ Embrapa Pesca e Aquicultura (CNPASA), Palmas, Brazil; ${ }^{3}$ Instituto \\ Nacional de Pesquisas da Amazônia (Inpa), Manaus, Brazil; ${ }^{4}$ Embrapa Amazônia Ocidental, Manaus, Brazil; ${ }^{5}$ Embrapa \\ Amapá, Laboratório de Sanidade de Organismos Aquáticos, Macapá, Brazil
}

\section{Summary}

The aim of this study was to investigate the effects of a dietary Allium sativum (garlic) addition on growth, parasite infestation and blood parameters in Colossoma macropomum (tambaqui) using 12 net-cages $\left(1 \mathrm{~m}^{3}\right)$. There were four treatments with three replicates each (15 fish per replicate). Tambaqui of $112.4 \mathrm{~g}$ mean weight were fed for 45 days with diets containing $0,15,30$ and $45 \mathrm{~g}$ of fresh garlic $\mathrm{kg}^{-1}$ feed. Garlic did not affect the tambaqui survival, growth, feed conversion, body condition, plasma glucose levels, total plasma protein levels or red blood cells. Total leukocyte and lymphocyte numbers decreased in fish fed diets containing $45 \mathrm{~g}$ garlic $\mathrm{kg}^{-1}$ feed, but neutrophils decreased in fish fed diets containing 15, 30 and $45 \mathrm{~g}$ garlic $\mathrm{kg}^{-1}$ diet, while the number of immature leukocytes increased in fish fed $30 \mathrm{~g}$ and $45 \mathrm{~g}$ garlic $\mathrm{kg}^{-1}$ diet. Gills in fish fed 30 and $45 \mathrm{~g} \mathrm{~kg}^{-1}$ diet had lower infestation (52\% and $63 \%$, respectively) of Anacanthorus spathulatus (Monogenea) compared to controls. The application of garlic in diets improved the response of leukocytes and enhanced the resistance to infections by monogeneans.

\section{Introduction}

The use of dietary additives is one method to improve growth performance, feed efficiency and disease resistance in fish farms (Yin et al., 2006; Shakya and Labh, 2014; Breyer et al., 2015; Pinheiro et al., 2015). Many plants or their byproducts have been used as fish feed additives, mainly to promote growth, stimulate appetite and enhance immuno-stimulation (Nya and Austin, 2009; Santos et al., 2009). Garlic, Allium sativum (Liliaceae), is one of these plants. Many plants used in fish farms contain natural organic substances that do not threaten fish health or the environment, but support the well-being of the cultured species.

Allicin is the main therapeutic component of garlic and accounts for its characteristic smell (Santos et al., 2009; Shakya and Labh, 2014; Breyer et al., 2015). The medicinal properties of allicin are associated primarily with the stimulation of glutathione S-transferase, an enzyme that participates in the detoxification of cell products or xenobiotics by catalization, that is, these compounds are more easily excreted because they become less toxic and more soluble in water.
Dially disulfide and trisulfide are other garlic compounds involved in the proliferation of immune system components such as T-cells and the cytokines produced by macrophages (Santos et al., 2009). Several studies have demonstrated the ability of diets with garlic, to upregulate immunity and increase resistance to various diseases in different fish species (Madsen et al., 2000; Buchmann et al., 2003; Chitmanat et al., 2005; Sasmal et al., 2005; Sahu et al., 2007; Nya and Austin, 2009; Shakya and Labh, 2014; Breyer et al., 2015).

The effects of garlic to decrease infections and prevent diseases as well as improve the performance and immunological response of fish have been observed mostly in temperate climate regions, with little information available for tropical fish. Administration of $1-2 \mathrm{~g} \mathrm{~kg}^{-1}$ dehydrated garlic in a 45 day diet contributed to the treatment of monogeneans Anacanthorus penilabiatus infestation in Piaractus mesopotamicus, in addition to improving their blood parameters (Martins et al., 2002). No there were studies using garlic to increase resistance in Colossoma macropomum Cuvier, 1818 (tambaqui). The tambaqui is an Amazon fish that frequently parasitized by monogenean species (Pinheiro et al., 2015), helminths of gills that cause diseases in this farmed fish. Therefore, could the use of garlic in the C. macropomum diet improve their growth and resistance to parasite infestations? The purpose of this study was to investigate the performance, monogenean infestations and blood parameters of tambaqui maintained in net-cages and fed with diets containing $A$. sativum.

\section{Materials and methods}

Colossoma macropomum fingerlings from the same brood were obtained from the fish farming unit of the hydroelectric power station of Balbina, Presidente Figueiredo, Amazonas state (Brazil). Fish were fed a commercial extruded diet with $32 \%$ crude protein (CP), crude $14.1 \%$ lipid and $23.3 \%$ crude carbohydrate, twice a day until they reached a mean weight of $112.4 \mathrm{~g}$. Fish were transported to 12 net-cages each $1 \mathrm{~m}^{3}$ in a 4-hectar lake of a local private fish farm. The cages were installed at $5 \mathrm{~m}$ distance from each other. There were four test conditions, each with three replicate cages (15 fish per cage).

Fresh A. sativum (garlic) was obtained from a grocery store. The garlic was peeled, ground in a blender and mixed 
into each diet $(32 \%$ crude protein) with the corresponding

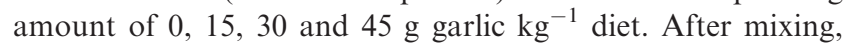
the feed was passed through a meat-grinder to produce pellets that were oven dried at $40^{\circ} \mathrm{C}$, ground and sieved through a $60 \mathrm{~mm}$ mesh.

The 12 net-cages were arranged in a completely randomized design. After being fed the garlic-enriched diets for 45 days, all fish were counted and measured to assess performance and calculate the relative condition factor (Le Cren, 1951). To evaluate blood parameters after the treatments, three fish were randomly captured from each replicate (total of nine fish per treatment) for blood samples taken by tail puncture, using syringes bathed in $10 \%$ EDTA. Blood samples were divided into two aliquots. One was centrifuged at $1440 \mathrm{G}$ to separate plasma, which was used for the determination of glucose (Trinder, 1969), total protein (Kruger, 1994) and ammonia (Gentzkow and Masen, 1942). The other blood aliquot was used to determine the concentrations of hematocrit and hemoglobin as well as to take red blood cell counts. These data were used to calculate mean corpuscular volume (MCV) and mean corpuscular hemoglobin concentration (MCHC). Blood smears were confectioned and stained with May GrünwaldGiemsa-Wright for thrombocyte counts, and total and differential leukocytes counts (Tavares-Dias and Moraes, 2006). The leukocytes were classified as lymphocytes, neutrophils, eosinophils, PAS-positive granular leukocytes (LG-PAS) and immature leukocytes (Pinheiro et al., 2015).

The gills of the three fish used for blood sampling were removed and fixed in 5\% formalin for collection, count and identification of monogeneans, according to Kritsky et al. (1979). The ecological terms (prevalence and intensity) used are those recommended by Bush et al. (1997). The efficacy of garlic treatment against monogeneans was determined according to Martins et al. (2002).

The temperature, dissolved oxygen and $\mathrm{pH}$ of the water were measured once a week at the surface of each net-cage using a digital device.

\section{Statistical analyses}

All data were previously evaluated under assumptions of normality and homoscedasticity using Kolmogorov-Smirnov and Bartlett tests, respectively. The treatments were compared using the analysis of variance (one-way ANOva) followed by Tukey $(\mathrm{P}<0.05)$ for means comparison (Zar, 1999).

\section{Results}

During the 45-day experiment the water quality parameters were within the optimum range for tropical fish (Table 1). The dietary treatments did not affect fish growth, survival, weight, total length, apparent feed conversion rate, or body conditions (Table 2). In tambaqui gills $100 \%$ infection by Anacanthorus spathulatus (Monogenea) was found, with a decrease observed in the mean intensity of these parasites in fish fed 30 and $45 \mathrm{~g}$ garlic $\mathrm{kg}^{-1}$ diet (Fig. 1).

Regarding blood parameters, the treatments showed no difference in levels of glucose or plasma protein, hematocrit, hemoglobin, red blood cell, MCV, MCHC, thrombocytes,
Table 1

Physical and chemical parameters in experimental net-cages $\left(1 \mathrm{~m}^{3}\right)$ for Colossoma macropomum fed different amounts of Allium sativum for 45 days. Data based on weekly determinations in each cage $(\mathrm{n}=18$ per cage $)$

\begin{tabular}{llll}
\hline $\begin{array}{l}\text { Garlic in the diets } \\
\left(\mathrm{g} \mathrm{kg}^{-1}\right)\end{array}$ & $\begin{array}{l}\text { Temperature } \\
\left({ }^{\circ} \mathrm{C}\right)\end{array}$ & $\begin{array}{l}\text { Dissolved oxygen } \\
\left(\mathrm{mg} \mathrm{L}^{-1}\right)\end{array}$ & $\mathrm{pH}$ \\
\hline 0 & $29.2 \pm 0.7$ & $5.2 \pm 1.5$ & $8.0 \pm 0.6$ \\
15 & $29.3 \pm 0.8$ & $5.3 \pm 1.4$ & $7.9 \pm 0.4$ \\
30 & $29.0 \pm 0.7$ & $5.0 \pm 1.5$ & $8.1 \pm 0.6$ \\
45 & $29.3 \pm 0.6$ & $5.2 \pm 1.3$ & $8.2 \pm 0.4$ \\
\hline
\end{tabular}

Values expressed as means $\pm \mathrm{SD}$.

monocytes, or LG-PAS (P > 0.05). Plasma ammonia was higher in treatments with 30 and $45 \mathrm{~g}$ garlic $\mathrm{kg}^{-1}$ diet (Table 3). Total leukocyte number was lower in the treatment with $45 \mathrm{~g} \mathrm{~kg}^{-1}$ of diet than in the control group, and the lymphocyte number in fish fed $45 \mathrm{~g} \mathrm{~kg}^{-1}$ diet was lower than in fish $30 \mathrm{~g} \mathrm{~kg}^{-1}$ diet. Neutrophils number was lower in treatment with 15,30 and $45 \mathrm{~g}_{\text {garlic }} \mathrm{kg}^{-1}$ diet than in controls. In fish fed with 30 and $45 \mathrm{~g} \mathrm{~kg}^{-1}$ diet, the immature leukocyte number was higher than in fish fed with 0 and

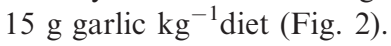

\section{Discussion}

In farm fish practices, garlic can be used in various forms such as aqueous or ethanol extracts or as dried powder. In the present study, garlic had no effect on growth parameters during the 45-day rearing. Similarly, diets containing dehydrated garlic also did not result in any improved growth in P. mesopotamicus during a 45-day trial (Martins et al., 2002). However, growth of Oreochromus niloticus (Shalaby et al., 2006; Metwally, 2009), Carassius auratus (Sasmal et al., 2005) and Oncorhynchus mykiss (Nya and Austin, 2009) was improved when these fish were fed diets containing garlic. Allicin is supposed to promote the intestinal flora, thereby improving digestion and energy utilization (Santos et al., 2009; Shakya and Labh, 2014; Breyer et al., 2015). Shakya and Labh (2014) found increased initial growth in red pacu, Colossoma brachypomum, followed by a decrease with increasing amounts of allicin. Although studies report that growth of fish is improved with garlic supplementation, high amounts of garlic can reduce feed intake because of its unpleasant odor and low palatability. Therefore, further studies are needed to confirm the effects of garlic on tambaqui growth.

The effects of garlic on infections are well known, thus this immunostimulatory plant is increasingly used to reduce parasitic infestations in farmed fish (Martins et al., 2002; Shalaby et al., 2006; Nya and Austin, 2009; Shakya and Labh, 2014; Breyer et al., 2015). The present study has shown such effects to reduce infestations by A. spathulatus in the fish gills. Similarly, for $P$. mesopotamicus fed diets containing garlic at $1,1.5$ and $2 \mathrm{~g} \mathrm{~kg}^{-1}$ diet for 15 days, Martins et al. (2002) reported reduced gill infestation rates by $A$. penilabiatus of 53,65 and $59 \%$, respectively. Therefore, such results support the use of garlic in diets when dealing with parasitic gill infections. 
Table 2

Culture performance of Colossoma macropomum reared for 45 days at a 15 fish per net-cage density $\left(1 \mathrm{~m}^{3}\right)$. Initial average weight $\left.=112.4 \mathrm{~g}\right)$. Fish were fed experimental diets containing different levels of Allium sativum

\begin{tabular}{|c|c|c|c|c|}
\hline \multirow[b]{2}{*}{ Parameters } & \multicolumn{4}{|c|}{ Garlic content in the diets $\left(\mathrm{g} \mathrm{kg}^{-1}\right)$} \\
\hline & 0 & 15 & 30 & 45 \\
\hline Final biomass $\left(\mathrm{kg} \mathrm{m}^{-3}\right)$ & $3.2 \pm 0.4$ & $3.3 \pm 0.7$ & $3.1 \pm 0.6$ & $3.4 \pm 0.5$ \\
\hline Biomass gain $\left(\mathrm{kg} \mathrm{m}^{-3}\right)$ & $1.6 \pm 0.4$ & $1.6 \pm 0.7$ & $1.4 \pm 0.6$ & $1.7 \pm 0.5$ \\
\hline Daily biomass gain ( $\mathrm{g} \mathrm{m}^{-3}$ day) & $48.0 \pm 21.0$ & $35.0 \pm 15.0$ & $32.0 \pm 14.0$ & $38.0 \pm 12.0$ \\
\hline Weight gain $(\mathrm{g})$ & $104 \pm 30$ & $107.0 \pm 46.0$ & $96 \pm 43$ & $113 \pm 36$ \\
\hline Daily weight gain $\left(\mathrm{g} \mathrm{day}^{-1}\right.$ ) & $2.3 \pm 0.7$ & $2.4 \pm 1.0$ & $2.1 \pm 0.9$ & $2.5 \pm 0.8$ \\
\hline Initial weight $(\mathrm{g})$ & $110.0 \pm 3.1$ & $111.0 \pm 2.5$ & $110.0 \pm 2.6$ & $112.0 \pm 2.7$ \\
\hline Final weight $(\mathrm{g})$ & $215.0 \pm 61.0$ & $218.0 \pm 80.0$ & $208.0 \pm 72.0$ & $225.0 \pm 86.0$ \\
\hline Initial length (cm) & $10.2 \pm 3.4$ & $11.1 \pm 2.2$ & $10.5 \pm 3.5$ & $11.0 \pm 4.0$ \\
\hline Final length $(\mathrm{cm})$ & $23.0 \pm 2.0$ & 23. \pm 3.0 & 22. \pm 4.0 & $23.0 \pm 3.0$ \\
\hline Survival $(\%)$ & 100 & 100 & 100 & 100 \\
\hline Feed conversion rate & $2.1 \pm 0.3$ & $19 \pm 0.2$ & $2.0 \pm 0.4$ & $1.7 \pm 0.3$ \\
\hline Relative condition factor & $1.00 \pm 0.3$ & $1.00 \pm 0.2$ & $1.00 \pm 0.4$ & $1.00 \pm 0.3$ \\
\hline
\end{tabular}

Values expressed as means $\pm \mathrm{SD} . \mathrm{N}=45$ fish by treatment ( 15 per replicate).

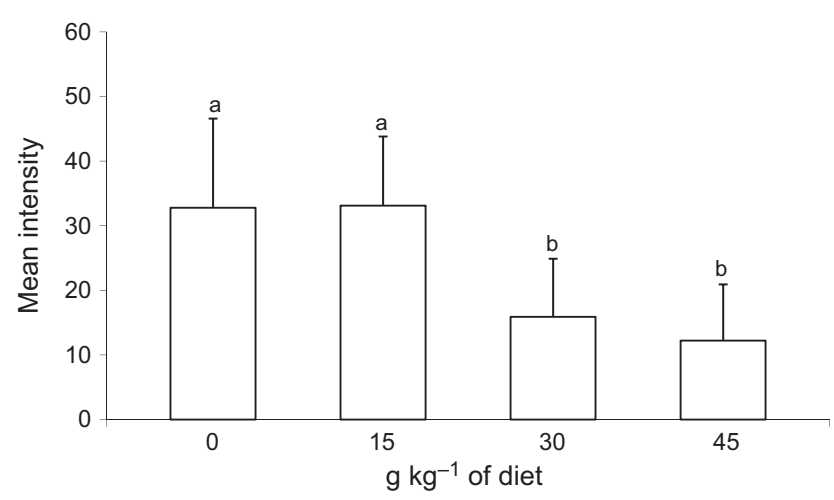

Fig. 1. Effect of different amounts of Allium sativum in diets of Colossoma macropomum with Anacanthorus spathulatus gill infestations. Data represent mean intensities (columns) and standard deviations (bars) of gill infestations after 45 days in net cages $\left(1 \mathrm{~m}^{3}\right)$. $\mathrm{N}=45$ fish per treatment (15 fish per replicate). Different letters over the bars $=$ statistically different $(\mathrm{P}<0.05)$

No differences in plasma glucose or total protein levels were detected in any garlic treatments in this study. By contrast, for Clarias lazera, diets with low garlic content caused hypoglycemia and an increase of glycogenesis in white muscles were detected by Al-Salahy (2002). Diets with garlic increased the total protein levels and reduced the serum glucose levels in O. niloticus (Shalaby et al., 2006) and Labeo rohita (Sahu et al., 2007). Garlic supplementation induced changes in serum total protein and globulin levels in rainbow trout infected with Aeromonas hydrophila and the increases in the serum total protein, albumin, and globulin contents reflected the innate immunity of the hosts (Nya and Austin, 2009). Furthermore, although stress conditions were not observed in this study, plasma ammonia levels increased in fish fed with diets containing a 30 or $45 \mathrm{~g}$ garlic diet ${ }^{-1}$, likely because of the increase in protein metabolism (Vieira et al., 2005). Therefore, a high garlic amount may be toxic for certain fish species (Martins et al.,
2002; Shakya and Labh, 2014). Thus, threshold levels should be established to safeguard the use in fish farms.

Hematological parameters, including erythrocyte and leukocyte counts, hemoglobin concentration and hematocrit can provide valuable indicators of fish health and stress responses (Martins et al., 2002; Tavares-Dias and Moraes, 2006; Davis et al., 2008; Nya and Austin, 2009). Increased oxygen consumption under stress often results in the release of mature red cells from hematopoietic organs (Sahu et al., 2007). Hence, increases in blood cells number, hematocrit and hemoglobin concentrations have been reported for $P$. mesopotamicus (Martins et al., 2002), Nile tilapia (Shalaby et al., 2006) and rainbow trout (Nya and Austin, 2009) fed garlic at various amounts and periods. However, in this study tambaqui showed similar hematological values in all test diets MCHC, indicating that they were not under stress since they were also subjected to more amenable management practices than in other studies.

Some garlic compounds play an important immunostimulatory role (Shalaby et al., 2006; Nya and Austin, 2009; Shakya and Labh, 2014; Breyer et al., 2015) and act on the functioning of the hematopoietic organs that regulate leucopoiesis (Shalaby et al., 2006). Piscine lymphocytes are involved in a number of immunological functions such as immunoglobulin production and mediation of defense mechanisms. Neutrophils, in turn, are the first leukocyte that participate in phagocytosis, whereas monocytes are long-lasting phagocytic cells associated with the fight against infections (Tavares-Dias and Moraes, 2006; Davis et al., 2008). In the present study where tambaqui fingerlings were fed a 15 or $30 \mathrm{~g}$ garlic $\mathrm{kg}^{-1}$ diet the total leukocyte and lymphocytes number were not altered, but were lower in fish fed $45 \mathrm{~g}$ garlic $\mathrm{kg}^{-1}$. However, in fish fed a diet with 15,30 or $45 \mathrm{~g}_{\text {garlic }} \mathrm{kg}^{-1}$ the neutrophils number increased, and the immature leukocyte number was higher in fish fed 30 or 45 garlic $\mathrm{kg}^{-1}$. Thus, there was a recruitment of immature leukocytes and decrease in neutrophil numbers in response to an infestation by $A$. spathulatus in 
Table 3

Blood parameters of Colossoma macropomum reared 45 days in net-cages $\left(1 \mathrm{~m}^{3}\right)$ and fed diets with different amounts of Allium sativum (garlic)

\begin{tabular}{|c|c|c|c|c|}
\hline \multirow[b]{2}{*}{ Parameters } & \multicolumn{4}{|c|}{ Garlic content in the diets $\left(\mathrm{g} \mathrm{kg}^{-1}\right)$} \\
\hline & 0 & 15 & 30 & 45 \\
\hline Ammonia $\left(\mu \mathrm{m} \mathrm{ml}^{-1}\right)$ & $2.9 \pm 0.4^{\mathrm{a}}$ & $2.8 \pm 0.4^{\mathrm{a}}$ & $4.0 \pm 0.5^{\mathrm{b}}$ & $4.6 \pm 0.8^{b}$ \\
\hline Total protein $\left(\mathrm{g} \mathrm{dl}^{-1}\right)$ & $2.8 \pm 0.2^{\mathrm{a}}$ & $2.7 \pm 0.4^{\mathrm{a}}$ & $2.3 \pm 0.5^{\mathrm{a}}$ & $2.7 \pm 0.4^{\mathrm{a}}$ \\
\hline Glucose $\left(\mathrm{mg} \mathrm{dl}^{-1}\right)$ & $45.4 \pm 7.2^{\mathrm{a}}$ & $48.4 \pm 3.9^{\mathrm{a}}$ & $51.4 \pm 8.2^{\mathrm{a}}$ & $55.4 \pm 10.0^{\mathrm{a}}$ \\
\hline Red blood cells $\left(\times 10^{6} \mu \mathrm{l}^{-1}\right)$ & $1.90 \pm 0.33^{\mathrm{a}}$ & $1.85 \pm 0.20^{\mathrm{a}}$ & $1.93 \pm 0.32^{\mathrm{a}}$ & $1.75 \pm 0.13^{\mathrm{a}}$ \\
\hline Hematocrit $(\%)$ & $28.4 \pm 1.6^{\mathrm{a}}$ & $28.7 \pm 1.0^{\mathrm{a}}$ & $28.4 \pm 1.9^{\mathrm{a}}$ & $29.1 \pm 1.3^{\mathrm{a}}$ \\
\hline Hemoglobin $\left(\mathrm{g} \mathrm{dl}^{-1}\right)$ & $7.2 \pm 0.6^{\mathrm{a}}$ & $7.5 \pm 0.5^{\mathrm{a}}$ & $7.8 \pm 1.0^{\mathrm{a}}$ & $7.6 \pm 1.3^{\mathrm{a}}$ \\
\hline $\operatorname{MCV}(\mathrm{fl})$ & $153.8 \pm 6.9^{\mathrm{a}}$ & $157.0 \pm 14.3^{\mathrm{a}}$ & $150.0 \pm 23.0^{\mathrm{a}}$ & $167.2 \pm 10.6^{\mathrm{a}}$ \\
\hline $\operatorname{MCHC}\left(\mathrm{g} \mathrm{dl}^{-1}\right)$ & $25.5 \pm 1.8^{\mathrm{a}}$ & $26.1 \pm 2.6^{\mathrm{a}}$ & $27.5 \pm 3.1^{\mathrm{a}}$ & $26.0 \pm 4.7^{\mathrm{a}}$ \\
\hline Thrombocytes $(\mu \mathrm{l})$ & $53079 \pm 15795^{\mathrm{a}}$ & $49115 \pm 14656^{\mathrm{a}}$ & $46649 \pm 23307^{\mathrm{a}}$ & $57121 \pm 9150^{\mathrm{a}}$ \\
\hline Monocytes $(\mu \mathrm{l})$ & $5529 \pm 3010^{\mathrm{a}}$ & $4371 \pm 2984^{\mathrm{a}}$ & $6185 \pm 4060^{\mathrm{a}}$ & $4528 \pm 1957^{\mathrm{a}}$ \\
\hline LG-PAS $(\mu \mathrm{l})$ & $1334 \pm 1131^{\mathrm{a}}$ & $1075 \pm 905^{\mathrm{a}}$ & $1232 \pm 1014^{\mathrm{a}}$ & $1846 \pm 696^{\mathrm{a}}$ \\
\hline Eosinophils $(\mu \mathrm{l})$ & $236 \pm 321^{\mathrm{a}}$ & $92 \pm 276^{\mathrm{a}}$ & $343 \pm 374^{\mathrm{a}}$ & $166 \pm 202^{\mathrm{a}}$ \\
\hline
\end{tabular}

Values expressed as means $\pm \mathrm{SD} . \mathrm{N}=9$ fish per treatment (three per replicate). LG-PAS: PAS-Positive granular leukocytes. Same letters in a row $=$ statistical similarity $($ Tukey test, $\mathrm{P}<0.05)$.
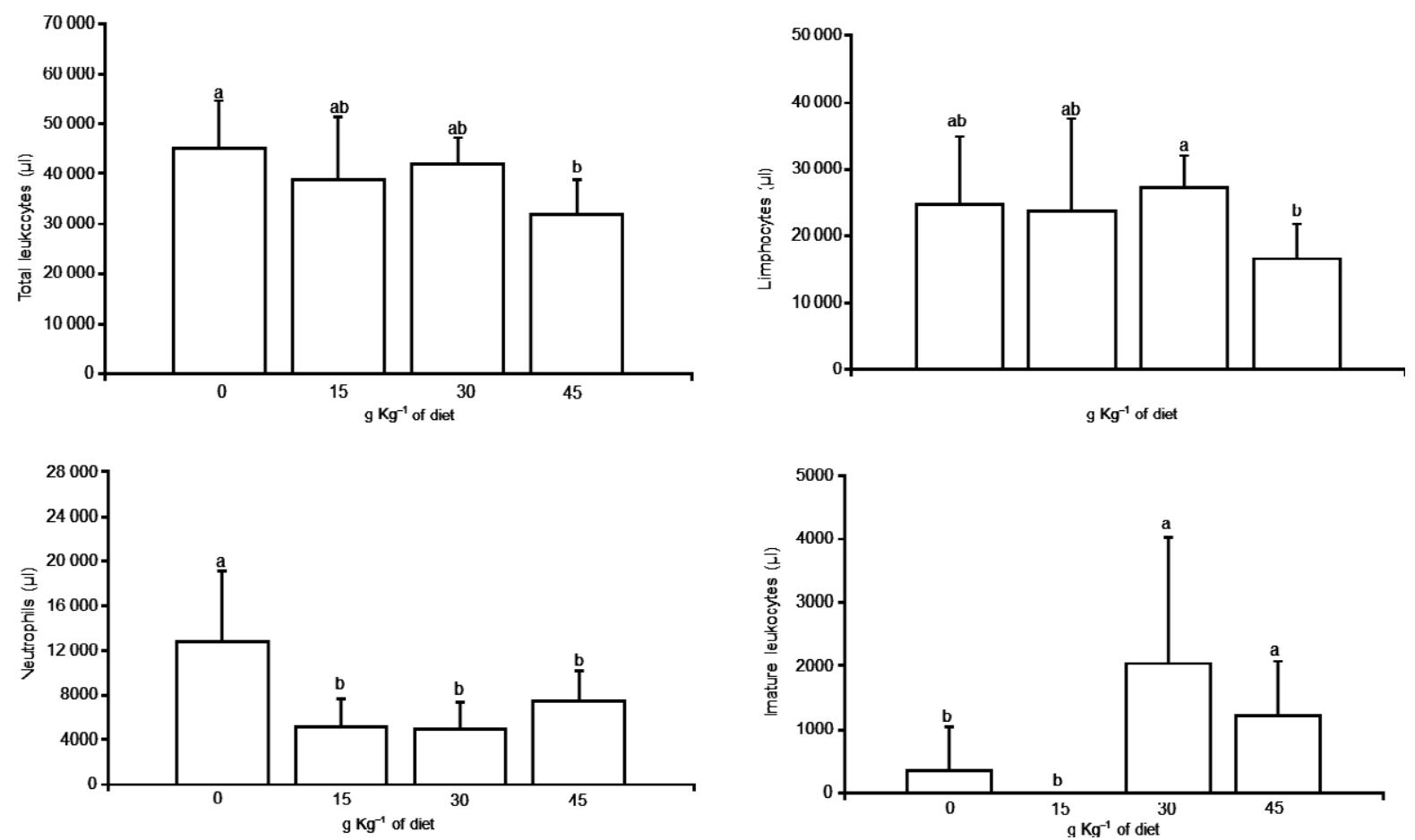

Fig. 2. Mean leukocyte numbers (columns) and standard deviations (bars) in Colossoma macropomum reared for 45 days in net-cages (1 $\mathrm{m}^{3}$ ) and fed diets containing different amounts of Allium sativum. $\mathrm{N}=$ sample size $=9$ fish per treatment (three fish per replicate). Similar letters over the bars $=$ statistical similarity $($ Tukey test, $\mathrm{P}<0.05$ )

the gills of the tambaqui. In contrast, for rainbow trout fingerlings (Nya and Austin, 2009) and rohu (Sahu et al., 2007) fed diets with garlic at $0.1,0.5$ or $1.0 \mathrm{~g} \mathrm{~kg}^{-1}$ the total leukocytes increased in number. For rainbow trout infected with $A$. hydrophila and fed diets of garlic at $0.5 \mathrm{~g} \mathrm{~kg}^{-1}$, when the garlic content was increased to $1.0 \mathrm{~g} \mathrm{~kg}^{-1}$, the lymphocyte numbers increased and the monocyte and neutrophil numbers decreased, possibly due to an increase of phagocytic activity (Nya and Austin, 2009). Therefore, such variations in leukocytes are expected in fish infected and immunostimulated by dietary garlic.

In conclusion, this study has shown that use of garlic might have an interesting, potential efficacy on the leukocytes, able to modulate the response to monogenean infections in tambaqui juveniles. Furthermore, further studies on the purification of bioactive compounds of garlic and their evaluation in tambaqui growth and immunity might improve the quality as well as the usage of these compounds in the fish farming intensivity of net-cages. 


\section{Acknowledgements}

We are grateful to the National Council for Scientific and Technological Development (CNPq, Brazil, \# 471263/07-9 and 471655/10-4), Embrapa (\#03.11.01.019.00.00; 03.08.15.07.00.00; 02.12.01.020.00.00; 02.13.09.002.00.00) and Amazonas State Research Foundation (FAPEAM, PAPAC \# 062.00890.2014) for supporting the study. M. Tavares-Dias was supported with a CNPq research fellowship (\#303203/2012-9).

\section{References}

Al-Salahy, M. B., 2002: Some physiological studies on the effect of onion and garlic juices on the fish Clarias lazera. Fish Physiol. Biochem. 27, 129-142.

Breyer, K. E.; Getchell, R. G.; Cornwell, E. R.; Wooster, G. A., 2015: Efficacy of an extract from garlic, Allium sativum, against infection with the furunculosis bacterium, Aeromonas salmonicida, in rainbow trout Oncorhynchus mykiss. J. World Aquac. Soc. 46, 273-282.

Buchmann, K.; Jensen, P. B.; Kruse, K. D., 2003: Effects of sodium percarbonate and garlic extract on Ichthyophthirius multifilis theronts and tomocysts: in vitro experiments. N. Am. J. Aquac. 65, 21-24.

Bush, A. O.; Booth, H.; Green, L. J.; Mckinley, A., 1997: Parasitology meets ecology on its own terms: Margolis et al. revisited. J. Parasitol. 83, 575-583.

Chitmanat, C.; Tongdonmuan, K.; Nunsong, W., 2005: The use of crude extracts from traditional medicinal plants to eliminate Trichodina sp. in tilapia (Oreochromis niloticus) fingerlings. Songklanakarin J. Sci. Tech. 27, 359-364.

Davis, A. K.; Maney, D. L.; Maerz, J. C., 2008: The use of leukocyte profiles to measure stress in vertebrates: a review for ecologists. Func. Ecol. 22, 760-772.

Gentzkow, C. J.; Masen, J. M., 1942: An accurate method for the determination of blood urea nitrogen by direct nesslerization. J. Biol. Chem. 143, 531-544.

Kritsky, D. C.; Thatcher, V. E.; Kayton, R. J., 1979: Neotropical Monogenoidea. 2. The Anacanthorinae Price, 1967, with the proposal of four new species of Anacanthorus Mizelle and Price, 1965, from Amazonian fishes. Acta. Amaz. 9, 355-361.

Kruger, N., 1994: The Bradford method for protein quantification. Met. Mol. Biol. 32, 9-15.

Le Cren, E. D., 1951: The length-weight relationship and seasonal cycle in gonadal weight and condition in the perch (Perca fluviatilis). J. Anim. Ecol. 20, 201-219.

Madsen, H. C. K.; Buchmann, K.; Mellergaard, S., 2000: Treatment of trichodiniasis in eel (Anguilla anguilla) reared in recirculation systems in Denmark: alternatives to formaldehyde. Aquaculture 186, 221-231.

Martins, M. L.; Moraes, F. R.; Miyazaki, D. M. Y.; Brum, C. D.; Onaka, E. M.; Fenerick, J. Jr; Bozzo, F. R., 2002: Alternative treatment for Anacanthorus penilabiatus (Monogenea: Dactylogyridae) infection in cultivated pacu Piaractus mesopotamicus (Osteichthyes: Characidae) in Brazil and their haematological effects. Parasite 9, 175-180.

Metwally, M. A. A., 2009: Effects of garlic (Allium sativum) on some antioxidant activities in Nile tilapia (Oreochromis niloticus). World J. Fish. Mar. Sci. 1, 56-64.

Nya, E. J.; Austin, B., 2009: Use of garlic (Allium sativum) to control Aeromonas hydrophila infection in rainbow trout Oncorhynchus mykiss (Walbaum). J. Fish Dis. 32, 963-970.

Pinheiro, D. A.; Caver, B. A. S.; Vargas, L.; Braccini, G. L.; Yoshioka, E. T. O.; Oliveira, M. S. B.; Tavares-Dias, M., 2015: Performance, parasitic infections, hematology and hepatic histology of Colossoma macropomum (tambaqui) fed on homeopathic product. Afr. J. Pharm. Pharmacol. 9, 82-90.

Sahu, S.; Das, B. K.; Mishra, B. K.; Pradhan, J.; Sarang, N., 2007: Effect of Allium sativum on the immunity and survival of Labeo rohita infected with Aeromonas hydrophila. J. Appl. Ichthyol. 23, 80-86.

Santos, E. L.; Ludke, M. C. M. M.; Lima, M. R., 2009: Extratos vegetais como aditivos em rações para peixes. Nutritime 6, 789800 .

Sasmal, D.; Babu, C. S.; Abraham, T. J., 2005: Effect of garlic (Allium sativum) extract on the growth and disease resistance of Carassius auratus (Linnaeus, 1978). Indian J. Fish. 52, 207-214.

Shakya, S. R.; Labh, S. N., 2014: Medicinal uses of garlic (Allium sativum) improves fish health and acts as an immunostimulant in aquaculture. Europ. J. Biotech. Biosci. 2, 44-47.

Shalaby, A. M.; Khattab, Y. A.; Abdel-Rahman, A. M., 2006: Effects of garlic (Allium sativum) and chloramphenicol on growth performance, physiological parameters and survival of Nile tilapia (Oreochromis niloticus). J. Venom Anim. Toxins Trop. Dis. 12, 172-201.

Tavares-Dias, M.; Moraes, F. R., 2006: Hematological parameters for the Brycon orbignyanus Valenciennes, 1850 (Osteichthyes, Characidae) intensively bred. Hidrobiológica 16, 271-274.

Trinder, P., 1969: Determination of glucose in blood using glucose oxidase with an alternative oxygen acceptor. Anim. Clin. Biochem. 6, 24-27.

Vieira, V.; Inoue, L. A. K. A.; Moraes, G., 2005: Metabolic responses of matrinxã (Brycon cephalus) to dietary protein level. Comp. Bioch. Physiol. 140, 337-342.

Yin, G.; Jeney, G.; Racz, T.; Xu, P.; Jun, X.; Jeney, Z., 2006: Effect of two Chinese herbs (Astragalus radix and Scutelaria radix) on non-specific immune response of tilapia Oreochromis niloticus. Aquaculture 253, 39-47.

Zar, J. H., 1999: Biostatistical analysis. Prentice-Hall, New Jersey, pp. 1-663.

Author's address: Marcos Tavares-Dias, Embrapa Amapá, Rodovia Juscelino Kubitschek, km 5, No 2600, 68903-419, Macapá, AP, Brazil.

E-mail: marcos.tavares@embrapa.br 